\title{
GENETIC VARIABILITY, HERITABILITY AND SELECTION RESPONSE FOR YIELD ATTRIBUTES IN NINE RICE (Oryza sativa L.) GENOTYPES
}

\author{
Khan, A., S. M. A. Shah, A. Sohail ${ }^{1}$, A. Haleem ${ }^{3}$, M. Maryam, T. Burni ${ }^{2}$ and M. Asad ${ }^{2}$ \\ Department of Plant Breeding and Genetics, The University of Agriculture, Peshawar, Khyber \\ Pakhtunkhwa-Pakistan; ${ }^{1}$ Key laboratory of Zhejiang Super Rice Research and State Key Laboratory of \\ Rice Biology, China National Rice Research Institute, Hangzhou-China; ${ }^{2}$ Department of Botany, \\ University of Peshawar Khyber Pakhtunkhwa-Pakistan; ${ }^{3}$ Oil Seed Directorate Sariab Quetta, Pakistan
}

\begin{abstract}
Genetic variability, heritability and selection response were studied among rice genotypes for yield attributing traits. Nine rice genotypes were evaluated in randomized complete block design with two replications at the University of Agriculture Peshawar-Pakistan during 2018. Significant differences were observed among the rice genotypes for all the traits. Pakhal took maximum value for Culm length $(113.6 \mathrm{~cm})$, Panicle length $(29.05 \mathrm{~cm})$, Secondary branches panicle ${ }^{-1}(31.4)$, Grain length $(10 \mathrm{~mm})$, Spikelets panicle ${ }^{-1}$ (162.8) and Grains panicle ${ }^{-1}(122.7 \mathrm{~g})$. However genotype NIAB-IR-8 took maximum value for 100 grain weight ( $2.9 \mathrm{~g})$ and Grain yield plant ${ }^{-1}(30.28 \mathrm{~g})$. High heritability and genetic advance were observed for all the studied traits viz. Culm length (0.95 and 27.77), Panicle length (0.84 and 3.83), Grain length (0.62 and 0.78), Secondary branches panicle ${ }^{-1}\left(0.66\right.$ and 6.19), Spikelets panicle ${ }^{-1}$ (0.59 and 21.82), Grains panicle ${ }^{-1}(0.75$ and 15.82), 100 grain weight ( 0.76 and 0.31$)$ and Grain yield plant ${ }^{-1}(0.95$ and 13.34). On the basis of superiority for yield attributing traits Pakhal and NIAB-IR- 8 could be recommended for future use in rice breeding programs.
\end{abstract}

Key words: Rice (Oryza sativa L.); Genetic variability; Heritability; Selection response; Correlation.

\section{INTRODUCTION}

Rice (Oryza sativa L.) belongs to the tribe Oryzeae. The genus Oryza consists of two cultivated species Oryza sativa (Asian species) and Oryza glaberrima (African species) and about 20 wild species. Only $O$. sativa is composed of two major biotypes or sub-species indica and japonica and represent evolutionary adaptation to environmental variables (Maclean et al. 2002).

The presence of rice in food economy of early man was found around $5000 \mathrm{BC}$ in China and India from archaeological excavations. On global basis, rice is planted on area of 153 million hectares with total production of 672 million tons. China is the largest producer of rice (196 million tons) followed by India (133 million tons), Indonesia (64 million tons), Bangladesh (47 million tons), Vietnam (38 million tons) and Myanmar (32 million) tons. In Pakistan rice is planted on an area of 2.3 million hectares with total production of 7.2 million tons (FAOSTAT, 2017). 57\% of rice is grown on irrigated land, $25 \%$ on rain fed lowland, $10 \%$ on the uplands, $6 \%$ in deep-water, and 2\% in tidal wetlands (Chopra and Prakash 2002). It is a source of magnesium, thiamine, niacin, phosphorus, vitamin B6, zinc and copper. Some varieties have iron, potassium and folic acid. White rice is one of the poorest cereals in proteins; some improved varieties however may provide $14 \mathrm{~g}$ of protein per $100 \mathrm{~g}$. A number of energy rich compounds such as carbohydrates, fats, proteins and reasonable amount of calcium and riboflavin are found in rice (Juliano and Villareal 1993).

Rice is the second most important food crop in Pakistan. It is planted not only in respect of local consumptions but also in view of large exports. In Pakistan rice crop was cultivated on an area of 2.78 million hectares with a production of 6.79 million tones and total yield was $2437 \mathrm{~kg} \mathrm{ha}^{-1}$ (FAOSTAT, 2017). Khyber Pakhtunkhwa contributes 0.04 million hectares with production of 0.08 million tons (FBS 2018). In the northern areas of the Khyber Pakhtunkhwa cool tolerant rice genotypes are grown, while in the southern areas of Khyber Pakhtunkhwa, IRRI type long grain high temperature stress tolerant rice 
genotypes are grown. Two provinces of Pakistan, i.e. Punjab and Sindh, are the main rice growing regions with nearly 50\% area in each province. In Pakistan, besides its importance as a food crop, about $23 \%$ of the total foreign exchange earnings is shared by rice and is called as "Golden grain of Pakistan" (Shah et al. 1999).

In Pakistan, rice is grown under diverse climatic, hydrological and edaphic conditions and is divided into four distinct agro ecological zones. The first zone consists of northern mountainous areas of the country and irrigated rice is grown in either flat valleys or terraced valley sides. The second zone lies in the broad strip of land between the rivers Ravi and Chenab where both canal and subsoil water are used for irrigation. The large tract of land on the west bank of the river Indus constitutes the third zone. While the fourth zone is the Indus delta, which consists of vast spill flats and basins; the latter are mostly irrigated (Chaudri 1986).

The presence of genetic variation for the desired traits constitutes the basis of plant breeding programs. Success of any crop improvement programme largely depends on the magnitude and range of variability on the available genetic stock. Critical estimate of genetic variability is a prerequisite for initiating appropriate breeding procedures in crop improvement programms. Information of genetic variability among yield and associated traits in rice has been reported by many workers (Sivasubramanian and MadhavaMenon 1973, Latif and Zamin 1965).

Assessment of the levels and patterns of genetic variability is of the immense significance in crop breeding programs for diverse applications which includes; (1) Analysis of genetic variability in landraces, accessions and wild relatives of crops for the morphological characteristics (Cox et al. 1986), (2) Identification of diverse parental combinations to create segregating progenies with sufficient genetic variability for onward selection (Barret and Kidwell 1998) (3) Introgression of desirable genes from diverse germplasm sources into the available narrow genetic base cultivars. Despite the richness of the genetic resources, only a small proportion of world rice germplasm collections have been used in breeding programs. Consequently, a genetic similarity is found within several commercial rice germplasm around the world (Guimaraes et al. 1995; Rangel et al. 1996). The limited use made of the rice genetic diversity available worldwide, has been the concern of rice breeders for the last few years. Identification of desirable germplasm sources can contribute significantly to broaden the narrow genetic base of the existing cultivars for bringing another green revolution in rice crop.

According to Raje and Rao (2000) genetic variability is essential in order to realize response to the selection. The estimates of genetic parameters of variation are specific for a particular population and the phenotypic expression of the quantitative characters may be altered by the environmental stresses that affect plant growth and development. Analysis of variability among the traits and the association of a particular character in relation to other traits contributing to the yield of a crop would be of a great importance in planning a successful breeding program (Mary and Gopalan 2006). The observed variability is a combined estimate of genetic and environmental causes, of which only the former is heritable. However, the estimates of heritability alone do not provide an idea about the expected gain in the next generation, but it has to be considered in conjugation with the estimates of genetic advance, the change in mean value between generations. The objective of present study is to assess the genetic variability among rice genotypes for yield relating traits and to identify superior rice genotypes for Peshawar valley.

\section{MATERIAL AND METHODS}

The experiment was conducted at the Department of Plant Breeding and Genetics Research farm, University of Agriculture, Peshawar Khyber Pakhtunkhwa during rice crop growing season 2018. Nine rice genotypes viz. NIAB-IR-8, NIAB-IR-9, Pakhal, IR-8, Kashmiri Basmati, DR-82, DR-83, Dokri Basmati and Sugdesi were planted in randomized complete block design with two replications. Each 
genotype was planted in four rows each of which was three meter long and the distance between two consecutive side by side row is $30 \mathrm{~cm}$. Seeding was raised in well prepared seedbeds on $12^{\text {th }}$ May 2017. Genotypes took 7 to 8 days to seedlings emergence. The seedlings were transplanted to well puddle field on $04^{\text {th }}$ June 2017. Uniform agronomic practices were performed for all genotypes. Data were recorded on culm length, panicle length, secondary branches panicle ${ }^{-1}$, grain length, spikelets panicle ${ }^{-1}$, grains panicle $^{-1}, 100$ grain weight and grain yield plant ${ }^{-1}$.

The data obtained after compilation were statistically analyzed using Mstat-C software for randomized complete block design. Mean separation was carried out following LSD (0.05) test. Heritability was calculated according to Allard (1960).

$$
\begin{gathered}
h^{2}(\text { b.s })=\sigma^{2} \mathrm{G} / \sigma^{2} \mathrm{P} \\
\mathrm{h}^{2}(\mathrm{~b} . \mathrm{s})=\text { broad sence heritability, } \sigma^{2} \mathrm{G}=\text { genotypic variance and } \sigma^{2} \mathrm{P}=\text { phenotypic variance }
\end{gathered}
$$

Genetic advance was estimated according to Fehr (1987).

$$
\mathrm{GA}=\mathrm{k} \cdot \mathrm{h}^{2} \cdot \sigma \mathrm{P}
$$

$\mathrm{GA}=$ genetic advance, $\mathrm{k}=$ selection intensity, $\sigma \mathrm{P}=$ phenotypic standard deviation

\section{Culm, Panicle and Grain length}

\section{RESULTS AND DISCUSSION}

Analysis of variance showed highly significant differences for culm and panicle length while significant difference was observed for grain length. Means of culm, panicle and grain length were 94.8, 25.8 and 9.4, respectively. Coefficient of variations for culm, panicle and grain length was 3.52, 3.50 and $3.97 \%$, respectively. High heritability was noted for culm length (0.95), panicle length (0.84) and grain length (0.62) with a genetic advance of 27.77 for culm length, 3.83 for panicle length and 0.78 for grain length. Our results are in line with Bhadru et al. (2012), Osman et al. (2012) and Ashfaq et al. (2012), who also noted highly significant differences among rice genotypes for panicle length and grain length.

\section{Secondary branches, Spikelets panicle ${ }^{-1}$, Grains panicle $e^{-1}$}

Mean squares revealed significant differences $(\mathrm{P} \leq 0.05)$ among rice genotypes for secondary branches panicle $^{-1}$ and spikelet panicle ${ }^{-1}$. While highly significant differences were noted for grain panicle $^{-1}$ (Table 1). Means of secondary branches, spikelets and grains panicle ${ }^{-1}$ were ranged from 31.4, 162.8 and 122.7 respectively. Coefficient of variation for secondary branches, spikelets and grains panicle $^{-1}$ was $10.52,8.45$ and $4.73 \% \mathrm{~m}$, respectively.

Table 1. Analysis of the coefficient of variation for yield attributes in nine rice genotypes.

\begin{tabular}{lcccc}
\hline Traits & $\begin{array}{c}\text { Replication } \\
(\mathbf{d f}=\mathbf{1})\end{array}$ & $\begin{array}{c}\text { Genotypes } \\
(\mathbf{d f}=\mathbf{8})\end{array}$ & $\begin{array}{c}\text { Error } \\
(\mathbf{d f}=\mathbf{8})\end{array}$ & $\begin{array}{c}\text { Coefficient of } \\
\text { variation }(\boldsymbol{\%})\end{array}$ \\
\hline Culm length & 0.06 & $395.8^{* *}$ & 11.16 & 3.52 \\
Panicle length & 0.21 & $9.0^{* *}$ & 0.81 & 3.50 \\
Grain length & 0.02 & $0.60^{*}$ & 0.14 & 3.97 \\
Secondary branches panicle $^{-1}$ & 38.72 & $34.1^{*}$ & 6.91 & 10.52 \\
Spike lets panicle $^{-1}$ & 339.73 & $514.1^{*}$ & 132.99 & 8.45 \\
Grains panicle $^{-1}$ & 96.14 & $183.2^{* *}$ & 26.06 & 4.73 \\
100-grain weight & 0.03 & $0.07^{* *}$ & 0.01 & 7.01 \\
Grain yield plant $^{-1}$ & 36.31 & $91.15^{* *}$ & 2.53 & 8.35 \\
\hline
\end{tabular}

$*$ and $* *$ significant at $5 \%$ and $1 \%$ probability level, respectively 
The estimated heritability for secondary branches panicle ${ }^{-1}$ was 0.66 , spikelets panicle ${ }^{-1}$ was 0.59 and grains panicle ${ }^{-1}$ was 0.75 . The genetic advance of secondary branches panicle ${ }^{-1}$ was 6.19 , spikelets panicle $^{-1}$ was 21.82 and grains panicle ${ }^{-1}$ was 15.82 . Our findings are in correspondence with Rahman et al. (2015) Sajid et al. (2015) and Akinwale et al. (2011).

100-Grain weight and grain yield plant ${ }^{-1}$

Highly significant differences $(\mathrm{P} \leq 0.01)$ were observed among rice genotypes for 100 -grain weight and grain yield plant ${ }^{-1}$ (Table 2). Mean values of 100-grain weight and grain yield plant ${ }^{-1}$ was 2.5 and $3.8 \mathrm{~g}$. Coefficient of variation for 100-grain weight and grain yield plant ${ }^{-1}$ was 7.01 and 8.35 respectively.

Table 2. Mean values of yield attributes of nine rice genotypes.

\begin{tabular}{|c|c|c|c|c|c|c|c|c|}
\hline Genotypes & $\begin{array}{l}\text { Culm } \\
\text { length }\end{array}$ & $\begin{array}{l}\text { Panicle } \\
\text { length }\end{array}$ & $\begin{array}{l}\text { Grain } \\
\text { length }\end{array}$ & $\begin{array}{c}\text { Secondary } \\
\text { branches } \\
\text { panicle }^{-1}\end{array}$ & $\begin{array}{c}\text { Spikelets } \\
\text { panicle }^{1}\end{array}$ & $\begin{array}{c}\text { Grain } \\
\text { Panicl }^{-1}\end{array}$ & $\begin{array}{c}100 \text { grain } \\
\text { weight }\end{array}$ & $\begin{array}{c}\text { Grain yield } \\
\text { plant }^{-1}\end{array}$ \\
\hline NIAB-IR-8 & 78 & 24.62 & 9.61 & 26.5 & 139.2 & 116.1 & 2.5 & 30.28 \\
\hline NIAB-IR-9 & 107 & 25.79 & 9.47 & 24.3 & 128.7 & 95 & 2.2 & 13.20 \\
\hline Pakhal & 103 & 29.05 & 10.00 & 31.4 & 162.8 & 122.7 & 2.2 & 20.90 \\
\hline IR-8 & 84.2 & 24.11 & 8.99 & 29.1 & 155 & 116.2 & 2.4 & 27.55 \\
\hline Kashmiri Basmati & 104.9 & 25.33 & 9.16 & 25.1 & 133 & 101 & 2.1 & 10.46 \\
\hline DR-82 & 113.6 & 25.58 & 9.86 & 17 & 106.3 & 95.6 & 1.5 & 19.50 \\
\hline DR-83 & 99.4 & 28.8 & 8.25 & 21.6 & 132.3 & 105.3 & 1.03 & 13.60 \\
\hline Dokri Basmati & 72.9 & 22.35 & 9.40 & 24.5 & 133.4 & 110.1 & 1.9 & 21.19 \\
\hline Sugdesi & 90.5 & 26.35 & 9.22 & 25.5 & 138.2 & 108.8 & 2.3 & 15.35 \\
\hline Grand Mean & 94.8 & 25.8 & 9.4 & 25.0 & 136.5 & 107.9 & 2.2 & 19.1 \\
\hline $\operatorname{LSD}(0.05)$ & 7.70 & 2.08 & 1.40 & 6.06 & 26.59 & 11.77 & 0.32 & 8.04 \\
\hline
\end{tabular}

High heritability was noted for 100-grain weight $(0.76)$ and grain yield plant ${ }^{-1}(0.95)$ and the genetic advance for 100-grain weight and grain yield plant ${ }^{-1}$ was 0.31 and 13.34 , respectively. Sanghera et al. (2013), Dutta et al. (2013) and Gangashetty et al. (2013) also reported significant differences among rice genotypes.

Table 3. Variance components ( Vg, Ve and Vp), broad sence heritability $\left(h^{2}\right)$ and genetic advance (GA) of yield attributes of rice genotypes.

\begin{tabular}{lccccc}
\hline Traits & $\mathbf{V g}$ & $\mathbf{V e}$ & $\mathbf{V p}$ & $\mathbf{h 2}$ & GA \\
\hline Culm length & 192.32 & 11.16 & 203.48 & 0.95 & 27.77 \\
Panicle length & 4.13 & 0.81 & 4.94 & 0.84 & 3.83 \\
Grain length $_{\text {Secondary branches panicle }}^{-1}$ & 0.23 & 0.14 & 0.37 & 0.62 & 0.78 \\
Spikelets panicle $^{-1}$ & 13.62 & 6.91 & 20.53 & 0.66 & 6.19 \\
Grains panicle $^{-1}$ & 190.56 & 132.99 & 323.56 & 0.59 & 21.82 \\
100-Grain weight $_{\text {Grain yield plant }^{-1}}$ & 78.58 & 26.06 & 104.64 & 0.75 & 15.82 \\
& 0.03 & 0.01 & 0.04 & 0.76 & 0.31 \\
& 44.31 & 2.53 & 46.84 & 0.95 & 13.34 \\
\hline
\end{tabular}

It can be concluded on the basis of results obtained from this experiment that all the rice genotypes manifested genetic variability for majority of the studied traits, showing possibilities for an effective selection. Analysis of variance showed significant differences $(P \leq 0.01)$ among the rice genotype for Culm length, Panicle length, Grain length, Spikelets panicle ${ }^{-1}$, Grains panicle ${ }^{-1}, 100$ grain weight and Grain yield plant ${ }^{-1}$. However Secondary branches panicle ${ }^{-1}$ showed significant difference among genotypes. Culm length $(113.6 \mathrm{~cm})$, Panicle length $(29.05 \mathrm{~cm})$, Secondary branches panicle ${ }^{-1}(31.4)$, 
Grain length $(10 \mathrm{~mm})$, Spikelets panicle ${ }^{-1}$ (162.8) and Grains panicle ${ }^{-1}$ (122.7 g). However genotype NIAB-IR-8 took maximum value for 100 grain weight $(2.9 \mathrm{~g})$ and Grain yield plant ${ }^{-1}(30.28 \mathrm{~g})$. the present experiment indicated that genotype NIAB-IR-8 and Pakhal are potential genotypes for yield and yield associated traits and can be used in future rice breeding programms.

\section{REFERENCES}

Akinwale, M. G., G. Gregorio, F. Nwilene, B. O. Akinyele, S. A. Ogunbayo and A. C. Odiyi. 2011. Heritability and correlation coefficient analysis for yield and its components in rice (Oryza sativa L.). Afr. J. Pl. Sci. 5(3): 207-212.

Allard, R. W. 1960. Principles of Plant Breeding. John Wiley and Sons Inc., N.Y. 485pp.

Ashfaq, M., A. S. Khan, S. H. Khan and R. Ahmad. 2012. Association of various morphological traits with yield and genetic divergence in rice (Oryza sativa). J. Agric. Biol. 14(1):55-62.

Barret, B. A. and K. K. Kidwell. 1988. AFLP-based genetic diversity assessment among wheat cultivars.1. Crop. sci. 38: 1261-1271.

Bhadru, D., L. Krishna, M. L. Pasha and R. B. M. Naik. 2012. Effect of environment on genetic parameters of hybrid rice. Int. J. Appl. Biol. Pharm. Tech. 2: 183-187.

Chaudri, M. Y. 1986. Problems and prospects of rice cultivation in Pakistan. Progressive farming. 6: 611.

Chopra, V. L. and S. Prakash. 2002. Evolution and adaptation of cereal crops. Science Publishers. 295pp.

Cox, T. S., J. P. Murphy and D. M. Rodgers. 1986. Changes in genetic diversity in the red winter wheat. Proc. Natl. Acad. Sci. USA. 83: 5583-5586.

Dutta, P., P. N. Dutta and P. K. Borua. 2013. Morphological Traits as Selection Indices in Rice. J. Agr. Res. 1(3): 85-96.

FAOSTAT, 2017. FAO Statistical Programme of Work. Food and Agriculture Organization of the United Nations. 72 pp.

FBS. 2018. In: Agriculture Statistics of Pakistan. Ministry of Food and Agriculture, Federal Bureau of Statistics. Govt. Pak. Islamabad.

Fehr, W. R. 1987. Principles of cultivar development: Theory and Technique. Vol. 1. Macmillan, New York. $536 \mathrm{pp}$.

Gangashetty, P. I., P. M. Salimath and N. G. Hanamaratti. 2013. Genetic variability studies in genetically diverse non-basmati local aromatic genotypes of rice (Oryza sativa L.). Rice Genomics Gen. 42: 4-8.

Guimaraes, E. P., J. Borrero and Y. O. Rey. 1995. Genetic diversity of upland rice germplasm distribution in Latin America. Pesquisa Agropecuaria Brasileira. 31(3): 1187-1194.

Juliano, B. O. and C. P. Villareal. 1993. Grain quality evaluation of world rices. IRRI, Philippines., pp. 55-64.

Latif, A. and S. M. H. Zamin. 1965. A study of heritability of four yield contributing characters in rice. Pak. J. Biol. Agric. Sci. 8: 219-225. 
Maclean, J. L., D. C. Dawe, B. Hardy and G. P. Hettel. 2002. Rice Almanac Source Book for the Most Important Economic Activity on Earth. 3rd ed. CABI Publishing, Wallingford, UK. 257pp.

Mary S. S. and A. Goplan. 2006. Dissection of genetic attributes yield traits of folder cowpea in F3 and F4. J. Appl. Sci. 2: 805-808.

Osman, K. A., A. M. Mustafa, F. Ali, Z. Yonglain and Q. Fazhan. 2012. Genetic variability for yield and related attributes of upland rice genotypes in semi-arid zone (Sudan). Afr. J. Agric. Res. 7(33): 4613-4619.

Rahman, A., S. M. A. Shah, H. Rahman, I. H. Khalil, M. Ismaeel, M. A. Raza and I. A. Khan. 2015. Genetic variability for morphological parameters in $\mathrm{F}_{2}$ segregating population of rice. Pak. J. Bot. 47(5): 1759-1764.

Raje, R. S. and S. K. Rao. 2000. Genetic parameters of variation for yield and its components mungbean (Vigna radiata L.) over environment. Legume Res. 23: 211-216.

Rangel, P. H. N, E. P. Guimares and P. C. F. Neves. 1996. The genetic base of Brazilian irrigated rice cultivars. Pesquisa Agropecuaria Brasileira. 31: 349-357.

Sajid, M., S. A. Khan, H. Khurshid, J. Iqbal, A. Muhammad, N. Saleem and S. M. A. Shah. 2015. Characterization of rice (Oryza sativa L.) germplasm through various agro-morphological traits. Sci. Agric. 9(2): 83-88.

Sanghera, G. S., S. C. Kashyap and G. A. Parray. 2013. Genetic variation for grain yield and related traits in temperate red rice (Oryza Sativa L.) ecotypes. Nat. Sci. Biol. 5(3): 400-406.

Shah, R., M. Z. Sulemani, M. S. Baloch and G. Hassan. 1999. Performance of coarse rice genotypes in the plains of D. I. Khan. Pak. J. Biol. Sci. 2: 507-509.

Sivasubramanian, S. and P. M. Menon. 1973. Genotypic and phenotypic variability in rice. Madras Agric. J. 60(9-12): 1093-1096. 